\title{
Kamu Örgütlerinde Öz Liderlik Düzeyinin Belirlenmesi
}

\author{
DOI: 10.26466/opus.513433 \\ * \\ Ercan Yavuz - Batuhan Ayan ${ }^{* *}$ \\ * Dr. Öğretim Üyesi, Ankara Hacı Bayram Veli Üni., Turizm Fakültesi., Ankara / Türkiye \\ E-Posta: ercan.yavuz@hbv.edu.tr \\ ORCID: 0000-0003-3696-4832 \\ ** Ankara Hacı Bayram Veli Üni., Lisansüstü Eğitim Enst., Ankara/ Türkiye \\ E-Posta: ayanbatuhan@gmail.com \\ ORCID: $\underline{0000-0002-4105-1723}$
}

\section{Öz}

Bu araştırmada Ankara'da faaliyet gösteren kamu kurumlarındaki personelin öz liderlik düzeyinin belirlenmesi amaçlanmıştır. Bu amaçla Houghton ve Neck (2002) tarafindan geliştirilen ve Tabak vd. (2009) tarafından Türkçeye uyarlaması yapılan öz liderlik ölçeği kullanılmıştır. Bu ölçek; davranış odaklı stratejiler, doğal ödül stratejileri ve yapıcı düşünce modeli stratejileri olmak üzere 3 strateji ile kendini ödüllendirme, kendini cezalandırma, kendini gözlemleme, kendine hatırlatıcular belirleme, doğal ödüllere düşünceyi odaklama, kendine hedef belirleyerek başarll performans hayal etme, kendi kendine konuşma ve düşünce ve fikirleri değerlendirme olmak üzere 8 boyuttan oluşmaktadır. Araştırma kapsamında toplam 486 personele ulaşılmış ve 405 geçerli anket elde edilmiştir. Çalışmada elde edilen verilerin analizleri SPSS 24.0 paket programı kullanılarak gerçekleştirilmiştir. Yapılan analizlerde personelin cinsiyeti ile kendi kendine konuşma boyutu, toplam çalışma süresi ile kendini cezalandırma boyutu, yaşı ile kendini ödüllendirme ve kendini gözlemleme boyutları ve öğrenim durumu ile kendini gözlemleme boyutu arasında anlamlı bir ilişki bulunmuştur. Kısaca personelin demografik özellikleri ile daha çok davranış odaklı stratejiler arasında anlamlı bir ilişki tespit edilmiştir.

Anahtar Kelimeler: Öz liderlik, Öz liderlik Boyutları, İsgören 


\title{
Determination of Self-Leadership Level in Public Organizations
}

\begin{abstract}
In this study, we aimed to determine the self-leadership level of personnel in public organizations in Ankara. For this purpose, Self Leadership Scale which is developed by Houghton and Neck (2002) and adapted to Turkish by Tabak (2009) was used. This scale consists of 3 strategies which are behaviororiented strategies, natural reward strategies and constructive thinking model strategies and 8 dimensions which are self-rewarding, self-punishment, self-observation, self-reminders, focusing on thoughts for natural awards, imagining successful performance by setting goals for oneself, talking to himself and evaluating thoughts and ideas. In the study, 486 personnel were reached and 405 valid questionnaires were obtained. The data obtained from the study were analyzed by using SPSS 24.0 package program. In the analysis, a significant relationship was found between the gender of the staff and the self-talk dimention, between working time of staff and self-punishment dimention, between age of staff and selfrewarding and self-observing dimensions and between education status of the staff and self-observation dimentions. In addition, a significant relationship was found between the demographic characteristics of the personnel and behavior oriented strategies.
\end{abstract}

Keywords: Self-leadership, Self-leadership Dimensions, Employee 


\section{Giriş}

Tanımlandığı zamandan bu güne kadar geçen sürede öz liderlik kavramı pek çok araştırmacının ilgisini çekmiş ve performans, motivasyon, sağlık gibi konular üzerine etkileri araştırılmıştır. Ayrıca öz-liderlik ile kişilik, kültür, meslek grubu gibi faktörler arasında da ilişki olup olmadığ konularında çeşitli çalışmalar yapılmıştır. Sydänmaanlakka (2004) konunun önemini belirtmek için şu ifadeyi kullanmaktadır: “Öz liderlik tüm liderlik ve yönetim için temeldir çünkü eğer kendini yönetemezsen, başkalarına nasıl liderlik edebilirsin?" (Sydänmaanlakka, 2004, s.1).

Öz liderlik kavramının bu denli önemli olmasının bir nedeni hızla değişen iş ortamının esneklik, hızlı cevap verme, yaratıcllık ve yüksek öğrenme becerileri gerektirmesidir (Sydänmaanlakka, 2004 s.1). Başka bir deyişle modern ekonomiler giderek yaratıcı gelişmelere neden olan becerilere ve deneyimlere sahip bireylere bağımlıdır (Georgianna, 2015 s.1). Yani modern iş ortamı, birçok organizasyonda çalışanlardan kendi kendine karar verme, inisiyatif alma ve kendi kendini yönetebilme yetisi istemektedir (Phillips vd., 2017 s.324). Modern ekonomilerin ve hizla değişen ortamlarda faaliyet gösteren organizasyonların gelecekte ne tür yönetici ve/veya personele ihtiyaç duyacağını tanımlamak kolay değildir ancak onların ortak bir özelliği şu olabilir: iyi bir öz lider olmaları gerekecektir. Bu kişilerin yüksek onur ve özbilgiye (kendini tanıma) sahip olması gerektiği anlamına gelir. Tamamen beklenmedik durumlarla baş edebilecek esnek ve hızlı öğrenen kişiler olmalıdırlar. Çünkü öz liderlik, bir kişinin kendini daha iyi tanımasını ve daha iyi bir öz-anlayışla kendini yönlendirebilmesine imkân veren bir olanak sağlar (Sydänmaanlakka, 2004 s.1). Bu nedenle öz liderlik eğitimi, yirmi birinci yüzyıldaki çalışma ortamının sürekli değişen zorlukları için işgücünü hazırlamaya yardımcı olabilir (DiLiello ve Houghton, 2006 s.326).

Neck ve Houghton'un (2006) çalışmasına göre, iş tatmini, bağlılık, inovasyon / yaratıcılık, bağımsızlık, psikolojik güçlendirme, güven, öz-etkililik, olumlu etki ve takım gücü gibi bazı değişkenler, öz liderliğin potansiyel sonuçları olarak görülmektedir (Sesen, Tabak ve Arlı, 2017 s. 946). Ayrıca öz liderlik, çalışanların iş performansı ile pozitif anlamda ilişkili bir teknik olarak görülmektedir (Hauschildt ve Konradt, 2012 s.498). Öz liderliğin potansiyel sonuçları ile ilgili diğer çalışmalar da ise 
bir öğrenci örneğine göre, Prusya, Anderson ve Manz, farklı öz-liderlik stratejilerinin uygulanmasının, akademik öz-yeterlilik yoluyla akademik performansı etkili bir şekilde destekleyebileceğini bulmuştur. Carmeli, Meitar ve Weisberg, çalışanların öz liderliklerinin, yenilikçi çalışma davranışları ile pozitif olarak ilişkili olduğunu da ortaya koymuştur. Başka bir çalışma, daha fazla özerkliğe ve özgürlüğe izin veren bir çalışma ortamı göz önüne alındığında, daha yüksek öz-liderliğe sahip olan üyelerin daha yüksek iş tatmini seviyelerine sahip olduklarını göstermiştir (Shek vd., 2015 s.344). Literatürdeki araştırmaların sonuçlarından, öz liderlik kavramının kişilerin hayatlarında ulaşmak istedikleri seviyelere, başarmak istedikleri amaçlara ulaşmalarında önemli ve etkili bir faktör olduğu görülmektedir.

İş koşulları bugün geçmişte olduğundan farklıdır. Kamu sektörleri daha dinamik, karmaşık ve belirsiz hale gelmektedir (Sejeli ve Mansor, 2015 s.22). Bu nedenle de kamu sektöründeki personelin kendi kendini daha iyi yöneterek faaliyet göstermesi örgütsel amaçlara ulaşmadaki başarıyı sağlamayı daha olumlu bir şekilde etkileyecektir. Bu çalışmada, Ankara'da faaliyet gösteren ve hizmet sektöründe yer alan kamu kurumlarında çalışan personelin öz liderlik düzeyleri ölçülmeye çalışılmıştır.

\section{Öz liderlik Kavramı}

Öz liderlik kavramı ilk olarak Manz $(1983,1986)$ ve Manz ve Neck (2004) tarafından öz yönetim teorisinin bir uzantısı olarak geliştirilmiş ve önerilmiştir (Topper, 2009 s.561). Manz (1983) öz liderlik kavramını; bireylerin başarılı olmak için belirli bilişsel ve davranışsal stratejiler kullanarak kendilerini etkiledikleri, yönlendirdikleri ve kendi davranışlarını kontrol ettikleri bir süreç olarak tanımlamaktadır (Carmeli, Meitar ve Weisberg, 2006 s.76; Arlı ve Avcı, 2017 s.456). Bu yönetim kavramı öncelikle sosyal öğrenme literatüründen türetilmiştir. Manz $(1986 ; 1990)$ ile Neck ve Manz (1996b) öz-liderlik kavramını diğer iki kavram, öz-düzenleme ve öz-yönetim ile karşılaştırarak daha fazla aydınlatmıştır (Godwin, Neck ve Houghton, 1999 s.154).

Öz liderlik kavramı insanın sürekli olarak kendini geliştirebileceğini ve kendi kendinin lideri olabileceğini savunmaktadır (Yavuz, 2018 s.193). 
Başka bir ifade ile insanların kendilerini yönettikleri iddiasına dayanır ve insanların davranışlarının, diş müdahalelere maruz kalmasına rağmen sonuç olarak yine kişinin kendi içsel güdüleri onların davranışlarını şekillendirmektedir (Shek vd., 2015 s.343). Kariyer koçu Cathy Wasserman, öz liderliği şöyle tanımlar: “... iç ve diş kaynaklarınızın daha fazlasına erişmek, yolunuzu aktif olarak yönlendirmek ve vizyonunuza ulaşmak için size yaşam boyu araçlar sağlayan, kendini geliştirmeye yönelik sezgisel ve stratejik bir yaklaşım" (Aktaran: Topper, 2009 s.561).

Öz liderlik, örgütsel liderlik oluşturmanın temel ilkesidir. Bunun nedeni, personel arasında öz-liderliğin kurulmasını sağlamak, liderliğin tezahürüne yol açacaktır. Öz liderlik, kişisel etkiyle oluşur, davranış ve kişisel bakış açısı ile gelişir ve kendi kendini yönetme ile uygulanabilir (Malmir ve Azizzadeh, 2013 s.79).

Öz liderlik kavramı, bireylerin öz-farkındalıklarını, isteklerini, motivasyonlarını, bilişlerini ve davranışlarını ele alan çeşitli iç içe geçmiş stratejilerden oluşur. Öz liderlik, bireyin kendi yaşam alanını ve örgüt içerisindeki sorumluluklarını düzenleme, toplumsal bilinç düzeyini yükseltme ve işe, yaşama ve örgüte yönelik motivasyon düzeyini arttırma çabasıdır (Georgianna, 2007 s.570). Öz liderlik stratejileri genellikle davranış odaklı stratejiler, doğal ödül stratejileri ve yapıcı düşünce modeli stratejilerinden oluşan üç temel kategoriye ayrilır (Anderson ve Prussia, 1997; Manz ve Neck, 2004; Manz ve Sims, 2001; Prussia et al., 1998; Houghton et al. 2003) Bu kategorilere yönelik açıklamalara ise aşağıda yer verilmiştir.

\section{Davranış Odaklı Stratejiler}

Davranış odaklı stratejiler, özellikle örgütte yapılması gerekli olan ancak, bireyin isteksiz davranması bu isteksizliğin sebebini de ya görevin kendisine ait olmadığına ya da değer yargıları ile görevin çelişmesine inanmasıyla açıklanabilir (Neck ve Houghton, 2006 s.271). Bu stratejiler, özbilinçliliğin ve temel de, bazen tatsız davranışların yönetiminin geliştirilmesine yöneliktir. Bu stratejiler sayesinde birey kendi davranışlarının sebep ve sonuçlarını ortaya koyarak bireysel farkındalık seviyesi hakkında bir kanaate varabilir (Yavuz, 2018 s.194). 
Kendini Ödüllendirme: Kendini ödüllendirme, istenen davranışları ve hedef kazanımları etkin bir şekilde güçlendirmek için somut veya soyut bir şey kullanmak (Ricketts vd., 2012) olarak tanımlanabilir. Önemli bir başarı için zihinsel olarak kendini tebrik etmek ve zor bir projenin tamamlanmasıyla özel bir tatil gibi daha somut ödüller kendini ödüllendirme için kullanılabilir.

Kendini Cezalandırma: İstenen davranışları etkili bir şekilde gerçekleştirmek için kullanılabilir (Ricketts vd., 2012). Bireyin yapmış olduğu hatalardan veya almış olduğu kararlardan dolayı kendine dönük özeleştiride bulunması, hatta sıkça tekrar ettiği hatalarından dolayı kendini cezalandırma yoluna gitmesi ya da aynı hataları tekrar etmeme adına daha önceki kararlarını gözden geçirmesi bireyin bundan sonraki davranışlarında önemli bir etken olacaktır. Bununla birlikte, öz eleştiri ve suçluluk içeren kendine dönük aşırı yaptırımlar, performans açısından zararlı olabilir ve bundan kaçınılmalıdır (Neck ve Houghton, 2006, s.272).

Kendini Gözlemleme : Kişinin belirli davranışları ne zaman ve neden yaptıklarını anlamalarına neden olabilecek kendi davranışlarını gözlemlemek, belirli davranışları değiştirebilmeye veya ortadan kaldırabilmeye yardımcı olabilir (Ricketts vd., 2012). Ayrıca kendini gözlemleme, bireyin nasıl, ne zaman ve niçin belirli davranışlarda bulunduğuna dair farkındalığına odaklanmayı kapsar. Bu tür bir öz farkındalık, etkisiz ve verimsiz davranışları değiştirmek veya ortadan kaldırmak için gerekli bir ilk adımdır (D’Intino vd., 2007, s.106). Ayrıca birey, daha iyi performansa yol açabilecek kişisel hedefleri etkin bir şekilde belirleyebilir (Houghton ve Neck, 2002, s.673).

Kendine Hatırlatıcılar Belirleme: Kendine hatırlatıcılar belirleme stratejisi, çoğunlukla fiziksel objelerin kullanlması veya diğer bireylerin yardımıyla, yapılması gereken önemli işlerin kişiye hatırlatılmasını ifade etmektedir. (Ay, 2017, s.931). Böylelikle birey bu nesne ve kişileri dikkat odaklamaya yardımcı gibi algılamakta, onları gördügünde kendi yapması gereken davranışları anımsayarak kendisini motive edebilmektedir (Tabak, Sığrı ve Türküöz, 2013, s.217). 
Doğal Ödül Stratejileri: Doğal ödül stratejileri, insanların kendi faaliyetlerinde hoş ve zevkli özellikler yaratmalarına yardımcı olur, böylece görevlerin kendileri de doğal olarak ödüllendirilir. Doğal ödül stratejileri içsel motivasyonu, kendi kaderini tayin etme ve yetkinlik duygularını artırır (Norris, 2008, s.45).

İki temel doğal ödül stratejisi vardır. Birincisi, belirli bir faaliyete daha keyifli ve zevkli özellikler kazandırmayı içerir, böylece görevin kendisi de doğal olarak ödüllendirilir. İkinci strateji, dikkati bir görevin hoş olmayan yönlerinden uzaklaştırmak ve onu görevin ödüllendirici yönleriyle yeniden odaklamak suretiyle algıları şekillendirmekten ibarettir (Manz ve Neck, 2004; Manz ve Sims, 2001). Her iki stratejinin de, içsel motivasyonun iki temel mekanizması olan yetkinlik ve kendini belirleme duyguları yaratması muhtemeldir (Deci ve Ryan, 1985). Özetlemek gerekirse, doğal ödül stratejileri, performans artırıcı görevle ilgili davranışları harekete geçiren, yeterlilik ve kendi kaderini tayin etme duyguları yaratmaya yardımcı olacak şekilde tasarlanmıştır (Neck ve Houghton,2006, s.272).

\section{Yapıcı Düşünce Modeli stratejileri}

Yapıcı düşünce stratejileri, kişilerin altta yatan düşünce kalıplarını arzu edilen şekillerde değiştirebilmelerini sağlayan stratejilerdir (Müller ve Niessen, 2017, s.3). Yapıcı düşünce stratejileri, olumlu alışkanlık biçimleri yaratır ve kendi kendine yıkıcı konuşma, kendi kendine iyimser konuşma ile yer değiştirir (Norris, 2008, s.45). Ayrıca yapıcı düşünce stratejileri yapıcı düşünce kalıplarının ve performansı olumlu yönde etkileyebilecek alı̧̧kanlık biçimlerinin oluşmasını kolaylaştırmak için tasarlanmıştır (D’Intino vd., 2007, s.106). Yapıcı düşünce öz liderlik örnekleri olarak şunlar verilebilir; pozitif inançlar ve beklentiler ile negatif kendi kendine konuşma ve zihinsel görüntülemenin değiştirilmesi, isteyerek güç ve iradeyi harekete geçirme ve yönetme ve başarılı bir görev performansının zihinsel imgelerini kullanma, bununla birlikte yapıcı düşünce stratejileri kullanmanın girişimcilerin işlerinin gelecekteki zorlukları konusunda daha iyimser bir bakış açısına sahip olmalarına yardımcı olmasını da içermektedir (Georgianna, 2015, s.146). 
Hedef Belirleme: Kapsamlı bir literatür araştırması, zorlayıcı ve özel hedefler belirleme sürecinin bireysel performans seviyelerini önemli ölçüde artırabileceğini göstermektedir. Bireyin kendi belirlediği hedeflerle birlikte belirlediği ödüller, hedefleri gerçekleştirmek için gerekli çabayı sarf etmede önemli ölçüde yardımcı olabilir (D’Intino vd., 2007, s.106).

Başarılı Performans Hayal Etme : Bireyin, geleceğe dönük hayali olarak tecrübeler yaşaması, bir iş tamamlanmadan önce ya da faaliyete başlamadan önce zihninde hayali provalar yapması, başarılı performans hayal etmesi ve bu başarıyı kafasında canlandırılmasıdır (Dilidüzgün ve Emir, 2016, s.548).

Kendi Kendine Konuşma: Bireyin kendi kendine sözlü ya da sözsüz olarak yapıcı yönde telkinlerde bulunarak konuşması, ne yapmasının uygun olacağını kendisine hatırlatarak stres seviyesini azaltabilmesi, kendisini düzene sokabilmesi ve böylelikle de performans artışı sağlayabilmesi bu stratejiyi kısaca açıklamaktadır (Aktaran Ay, 2017, s.932).

Düşünce ve Fikirlerini Değerlendirme: Bireyler kendine kendilerine yaptıkları bir analiz yoluyla kendi düşünce modellerini değerlendirir, stresli ve güç durumlarda ortaya çıkan işlevi olmayan ve rasyonel olmayan düşünce ve öngörüleri tanımlar, onlarla yüzleşir ve onları daha mantıklı, yapıcı düşünce modelleri ile değiştirirler (Manz ve Neck, 1999). Böylece işlevsel olmayan düşünce ve fikirler bireyde depresyona neden olarak işgücü kaybına yol açmayacağı için daha yapıcı düşünce modelleri ile performans düşüklüğü yaşanmayacaktır (Dilidüzgün ve Emir, 2016, s.547).

\section{Yöntem}

\section{Araştırmanın Amacı ve Hipotezler}

$\mathrm{Bu}$ araştırmanın amacı Ankara'daki kamu kurumlarında çalışan personelin öz liderlik düzeylerinin belirlenmesidir. Araştırmanın hipotezleri aşağıdaki gibidir: 
- H1: Personelin cinsiyeti ile öz liderlik boyutları arasında anlamlı bir ilişki vardır.

- $\mathrm{H}_{2}$ : Personelin toplam çalışma süresi ile öz liderlik boyutları arasında anlamlı bir ilişki vardır.

- $\mathrm{H}_{3}$ : Personelin yaşı ile öz liderlik boyutları arasında anlamlı bir ilişki vardır.

- $\mathrm{H}_{4}$ : Personelin eğitim düzeyi ile öz liderlik boyutları arasında anlamlı bir ilişki vardır.

\section{Evren ve Örneklem}

Araştırmanın evrenini Ankara' da faaliyet gösteren ve hizmet sektöründe yer alan kamu kurumlarındaki personeller oluşturmaktadır. Ankara'daki tüm kamu personeline ulaşmanın çok zor olması nedeni ile araştırma evreninin tamamına ulaşılamamıştır. Araştırmada 486 personele ulaşılmıştır ancak elde edilen anketlerden 405 tanesi araştırmaya dâhil edilmiştir.

\section{Veri Toplama Aract}

Araştırmada bireylerin, öz liderlik davranışları sergileme düzeylerini belirlemek için Houghton ve Neck (2002) tarafından geliştirilen ve Tabak vd. (2009) tarafından Türkçeye uyarlaması yapılmış olan Öz Liderlik Ölçeği kullanılmıştır. Bu ölçekte, 3 temel boyut ve 8 alt boyut olmak üzere toplam 29 ifadeden oluşmaktadır.

Tablo 1. Öz Liderlik Ölçeğinin Temel Bileşenleri ve Alt Ölçekleri

\begin{tabular}{ccc}
\hline Öz Liderlik Ölçeği & $\begin{array}{c}\text { Madde } \\
\text { Sayısı }\end{array}$ & Madde Numarası \\
\hline Davranış Odaklı Stratejiler & & \\
\hline Kendini ödüllendirme & 3 & $3,10,19$ \\
Kendini cezalandırma & 4 & $5,12,21,26$ \\
Kendini gözlemleme & 4 & $6,13,22,27$ \\
Kendine hatırlatıcılar belirleme & 2 & 7,15 \\
\hline Doğal Ödül Stratejileri & 2 & \\
\hline Doğal ödüllere düşünceyi odaklama & & \\
\hline Yapıcı Düşünce Modeli Stratejileri & & \\
\hline
\end{tabular}




\begin{tabular}{lcc}
\hline $\begin{array}{l}\text { Kendine hedef belirleyerek başarılı perfor- } \\
\text { mans hayal etme }\end{array}$ & 7 & $1,8,16,17,23,24,28$ \\
& & \\
Kendi kendine konuşma & 3 & $2,9,18$ \\
Düşünce ve fikirleri değerlendirme & 4 & $4,11,20,25$ \\
\hline Toplam & & 29 \\
\hline
\end{tabular}

Ayrıca "Hiçbir Zaman", "Nadiren”, "Ara Sıra”, "Genellikle” ve "Her Zaman" sıklık seviyelerinden oluşan 5’li likert tipi ölçek kullanılmıştır.

\section{Bulgular}

\section{Güvenirlilik Analizi}

Bu çalışmada kullanılan anketin geçerlik güvenirlilik analizleri yapılmış ve ölçeğin genelinin güvenirlilik katsayısı 0.84 olarak bulunmuştur. Bu değerin $\alpha>0.8$ olması ise anketin yüksek güvenilirliğe sahip olduğunu göstermektedir.

\section{Demografik Özellikler}

Araştırma kapsamında Ankara'daki çeşitli kamu kurumlarında görev yapan 405 kamu personeline ulaşılmıştır.

Tablo 2. Araştırmaya Katılan Yöneticilerin Cinsiyet, Çalışma Süresi, Yaş ve Eğitim Dağılımları

\begin{tabular}{llcc}
\hline Demografik Özellikler & & $\mathbf{N}$ & $\mathbf{\%}$ \\
\hline Cinsiyet & Kadın & 224 & 55,3 \\
& Erkek & 181 & 44,7 \\
\hline Toplam Çalışma Süresi (Yıl) & $<5$ & 82 & 20,2 \\
& $6-10$ arası & 161 & 39,8 \\
& $11-15$ arası & 64 & 15,8 \\
& $16-20$ arası & 38 & 9,4 \\
& $>20$ & 60 & 14,8 \\
\hline Yaş & $<25$ & 97 & 24,0 \\
& $26-34$ arası & 127 & 31,4 \\
& $35-44$ arası & 111 & 27,4 \\
& $45-54$ arası & 62 & 15,3 \\
& $>55$ & 8 & 2,0 \\
\hline Öğrenim Durumu & Ön lisans & 95 & 23,5 \\
& Lisans & 262 & 64,7 \\
& Lisansüstü & 48 & 11,9 \\
\hline
\end{tabular}


Araştırmaya katılan kamu personelinin demografik özelliklere göre dağ 1 lımları tablo 2' de yer almaktadır. Bu tabloya göre araştırmaya katılan personelin \% 55,3'ü kadın, \% 44,7'si erkek, \% 24 'ü 25 yaşından küçük, \% 31,4'ü 26 - 34 yaş aralığında, \% 27,4'ü 35 - 44 yaş aralığında, \% 15,3'ü $45-$ 54 yaş aralığında ve \% 2'si 55 yaş üzeri, , \% 23,5'i ön lisans mezunu, \% 64,7'si lisans mezunu, \% 11,9'u lisansüstü bölümlerden mezun, \% 20,2'si 5 yıldan az süredir çalışmakta, \% 39,8'i 6 - 10 yıl arası çalışmakta, \% 15,8'i 11 - 15 yıl arası çalışmakta, \% 9,4'ü 16 - 20 yıl arası çalışmakta ve \% 14,8'i 20 yıldan fazla süredir çalışmaktadır.

\section{Bulgular}

Araştırmaya katılan Ankara'daki kamu kurumlarında çalışan personelin ankette yer alan ifadelere verdiği cevapların ortalamaları aşağıdaki tabloda yer almaktadır.

Demografik özellikleri değerlendirmeye katmadan önce personelin özliderlik düzeyi hakkında değerlendirme yapılmaya çalışılmıştır. Bu amaçla ifadelerin ortalama değerleri incelenmiş, ortalama değeri en yüksek ve en düşük olan ifadeler seçilmiştir.

Tablo 3. Ölçekteki ifadelerin ortalama ve standart sapma değerleri

\begin{tabular}{|c|c|c|}
\hline Öz liderlik Boyutları & $\begin{array}{c}\text { Ortalama } \\
(n=394)\end{array}$ & $\begin{array}{l}\text { Std. } \\
\text { Sapma }\end{array}$ \\
\hline $\begin{array}{l}\text { Önemli işlerde, başarımı üst düzeyde sergileyebilmek için hayal gücümü } \\
\text { kullanırım. }\end{array}$ & 3,64 & 1,224 \\
\hline $\begin{array}{l}\text { Karşılaştığım problemleri çözmeye çalışırken kimi zaman yüksek sesle, } \\
\text { kimi zaman da içimden kendi kendime konuşarak durumu gözden } \\
\text { geçirmeye çalışırım. }\end{array}$ & 3,62 & 1,125 \\
\hline $\begin{array}{l}\text { Bir görevi başardığımda, özellikle zevk aldığım bir şeyleri yaparak } \\
\text { kendimi ödüllendiririm. }\end{array}$ & 3,66 & 1,212 \\
\hline $\begin{array}{l}\text { Zor bir durumla karşılaştı̆̆ımda, kendi mantığıma başvurarak durumu } \\
\text { değerlendiririm. }\end{array}$ & 4,04 & 969 \\
\hline $\begin{array}{l}\text { Başarısız olduğum zamanlarda, kendimi yetersiz bulma eğilimindeyim- } \\
\text { dir. }\end{array}$ & 3,10 & 1,244 \\
\hline Mesleğimde ne kadar iyi olduğumu takip ederim. & 3,96 & ,990 \\
\hline Neyi başarmam gerektiğini hatırlamak için notlar kullanırım. & 3,39 & 1,253 \\
\hline $\begin{array}{l}\text { Bir işe başlamadan önce, kendimi o işi başarıyla tamamlamış gibi } \\
\text { hayalimde canlandırırım. }\end{array}$ & 3,60 & 1,191 \\
\hline
\end{tabular}


Zor koşullar altında çalışırken, kimi zaman kendi kendime konuştuğum

olur (yüksek sesle veya zihnimden).

Bir işi iyi yaptığımda, kendimi özel bir şekilde (iyi bir akşam yemeği,

sinema, alış veriş, seyahat, vb.) ödüllendiririm.

Sorun yaşadığım durumlar hakkındaki düşüncelerimin doğruluğunu

zihnimde tartmaya çalışırım.

Başarısız olduğum durumlarda kendime çok kızarım.

Bir işi yaparken ne kadar iyi olduğumun farkındayımdır.

Çevremde heyecanımı ve tutkumu diri tutan, bana pozitif enerji veren

kullanırım(notlar, listeler, vb.).

Bir işi yapmadan önce, o işi başarıyla yaptığımı kafamda tasarlarım.

ifade eder, gerekirse o düşünce ve fikirleri doğruluğu açısından değerlendirebilirim.

Bir işte yeterince başarılı olamadığım zamanlarda kendimi suçlu

Karşılaştı̆̆ım zorlukların üstesinden gelebildiğimi, özellikle gözümde canlandırırım.

Gelecekte ulaşmak istediğim hedefleri düşünürüm.

Fikirlerim ve inançlarım hakkında düşünür ve değerlendirmeler

yaparım.

Bir işi başaramadığım zaman, kendimle ilgili memnuniyetsizliğimi açık

Tablo 3 incelendiğinde araştırmaya katılan kamu personelinin en fazla 22. ifade olan "İşimi ne kadar iyi yaptığıma dikkat ederim." ifadesini tercih ettiği görülmektedir. Personelin en az 10. ifade olan "Bir işi iyi yaptığımda, kendimi özel bir şekilde (iyi bir akşam yemeği, sinema, alış veriş, seyahat, vb.) ödüllendiririm." ifadesini tercih ettiği görülmektedir. 
Tablo 4. Öz liderlik boyutlarmın ortalama ve standart sapma değerleri

\begin{tabular}{lccc}
\hline Öz liderlik Boyutları & n & Ortalama (․ㅜ) & $\begin{array}{c}\text { Standart } \\
\text { Sapma }\end{array}$ \\
\hline Kendini ödüllendirme & 405 & 3,4321 & 1,03705 \\
Kendini cezalandırma & 405 & 3,3623 & 0,76695 \\
Kendini gözlemleme & 405 & 3,9519 & 0,68295 \\
Kendine hatırlatıcılar belirleme & 405 & 3,4642 & 1,03972 \\
Doğal ödüllere düşünceyi odaklama & 405 & 3,8975 & 0,85524 \\
Kendine hedef belirleyerek başarılı perfor- & 405 & 3,8434 & 0,76850 \\
mans hayal etme & 405 & 3,5243 & 0,92322 \\
Kendi kendine konuşma & 405 & 3,9309 & 0,68160 \\
Düşünce ve fikirleri değerlendirme & 405 & & \\
\hline
\end{tabular}

Tablo 4 incelendiğinde araştırmaya katılan kamu personelinin en fazla "Kendini Gözlemleme" ve en az ise "Kendini Cezalandırma" öz liderlik boyutunu kullandığ1 görülmektedir.

Tablo 5. Cinsiyetin ile öz liderlik boyutları arasındaki ilişkiye ilişkin bağımsız örneklem t testi sonuçları

\begin{tabular}{|c|c|c|c|c|c|c|}
\hline Öz liderlik Boyutları & Cinsiyet & Ortalama & $\begin{array}{l}\text { Standart } \\
\text { Sapma }\end{array}$ & $t$ & df & $\mathbf{p}$ \\
\hline \multirow{2}{*}{ Kendini ödüllendirme } & Kadın & 3,4294 & 1,04872 & \multirow{2}{*}{0,121} & \multirow{2}{*}{401} & \multirow{2}{*}{0,904} \\
\hline & Erkek & 3,4420 & 1,02913 & & & \\
\hline \multirow{2}{*}{ Kendini cezalandırma } & Kadın & 3,3727 & 0,73486 & \multirow{2}{*}{0,430} & \multirow{2}{*}{401} & \multirow{2}{*}{0,668} \\
\hline & Erkek & 3,3398 & 0,80313 & & & \\
\hline \multirow{2}{*}{ Kendini gözlemleme } & Kadın & 3,9944 & 0,69151 & \multirow{2}{*}{1,475} & \multirow{2}{*}{401} & \multirow{2}{*}{0,141} \\
\hline & Erkek & 3,8936 & 0,66933 & & & \\
\hline \multirow{2}{*}{$\begin{array}{l}\text { Kendine hatırlatıcilar belir- } \\
\text { leme }\end{array}$} & Kadın & 3,5068 & 1,03500 & \multirow{2}{*}{1,021} & \multirow{2}{*}{401} & \multirow{2}{*}{0,308} \\
\hline & Erkek & 3,4006 & 1,04406 & & & \\
\hline \multirow{2}{*}{$\begin{array}{l}\text { Doğal ödüllere düşünceyi } \\
\text { odaklama }\end{array}$} & Kadın & 3,9527 & 0,85287 & \multirow{2}{*}{1,451} & \multirow{2}{*}{401} & \multirow{2}{*}{0,148} \\
\hline & Erkek & 3,8287 & 0,85372 & & & \\
\hline \multirow{2}{*}{$\begin{array}{l}\text { Kendine hedef belirleyerek } \\
\text { başarılı performans hayal } \\
\text { etme }\end{array}$} & Kadın & 3,8662 & 0,83317 & \multirow[b]{2}{*}{0,702} & \multirow[b]{2}{*}{401} & \multirow[b]{2}{*}{0,483} \\
\hline & Erkek & 3,8122 & 0,68006 & & & \\
\hline \multirow{2}{*}{ Kendi kendine konuşma } & Kadın & 3,6216 & 0,91024 & \multirow{2}{*}{2,395} & \multirow{2}{*}{401} & \multirow{2}{*}{0,017} \\
\hline & Erkek & 3,4015 & 0,92744 & & & \\
\hline \multirow{2}{*}{$\begin{array}{l}\text { Düşünce ve fikirleri değer- } \\
\text { lendirme }\end{array}$} & Kadın & 3,9887 & 0,69573 & \multirow{2}{*}{1,964} & \multirow{2}{*}{401} & \multirow{2}{*}{0,148} \\
\hline & Erkek & 3,8550 & 0,66041 & & & \\
\hline
\end{tabular}

Cinsiyet ile öz liderlik boyutları arasındaki ilişkiyi incelemek için bağımsız örneklem $t$ testi yapılmıştır. Bu testin sonucunda elde edilen veriler tablo 5 'te yer almaktadır. Öz liderlik boyutlarından kendini ödüllendirme, kendini cezalandırma, kendini gözlemleme, kendine hatırlatıcılar 
belirleme, doğal ödüllere düşünceyi odaklama, kendine hedef belirleyerek başarılı performans hayal etme ile düşünce ve fikirleri değerlendirme boyutlarının p değeri 0,05 'ten büyüktür. Sadece kendi kendine konuşma boyutunun $\mathrm{p}$ değeri 0,05 'ten küçüktür. Bu durumda sadece cinsiyet ile kendi kendine konuşma boyutu arasında anlamlı bir farklılık bulunmaktadır. Kadın çalışanların kendi kedine konuşma boyutunu kullanma düzeyi erkek çalışanlardan daha yüksektir.

Tablo 6. Toplam Çalışma Süresi ile öz liderlik boyutları arasındaki ilişkiye ilişkin varyansların homojenliği testi sonuçları

\begin{tabular}{lcccc}
\hline Öz liderlik Boyutları & $\begin{array}{c}\text { Levene İstatis- } \\
\text { tiği }\end{array}$ & df1 & df2 & p \\
\hline Kendini ödüllendirme & 1,326 & 4 & 400 & 0,260 \\
Kendini cezalandırma & 0,775 & 4 & 400 & 0,542 \\
Kendini gözlemleme & 1,306 & 4 & 400 & 0,267 \\
Kendine hatırlatıcılar belirleme & 3,196 & 4 & 400 & 0,053 \\
Kendine hedef belirleyerek başarılı perfor- & 1,022 & 4 & 400 & 0,396 \\
mans hayal etme & 1,424 & 4 & 400 & 0,225 \\
Kendi kendine konuşma & 1,017 & 4 & 400 & 0,398 \\
Düşünce ve fikirleri değerlendirme & 0,325 & 4 & 400 & 0,862 \\
Doğal ödüllere düşünceyi odaklama & & & &
\end{tabular}

Tablo 6 incelendiğinde $\mathrm{p}$ değerlerinin $0,05^{\prime}$ ten büyük olduğu görülmektedir. Bu durumda varyanslar homojen (eşit) dağılmıştır. Varyanslar homojen dağıldığından dolayı tek yönlü anova testi sonuçlarına bakılabilir. Tek yönlü anova testi sonuçları aşağıdaki çizelgedeki gibidir:

Tablo 7. Toplam çalışma süresi ile özliderlik boyutları arasındaki ilişkiye ilişkin ANOVA testi sonuçları

\begin{tabular}{lrc}
\hline Öz liderlik Boyutları & F & p \\
\hline Kendini ödüllendirme & 1,708 & 0,147 \\
Kendini cezalandırma & 1,606 & 0,027 \\
Kendini gözlemleme & 1,610 & 0,171 \\
Kendine hatırlatıcılar belirleme & 1,983 & 0,096 \\
Kendine hedef belirleyerek başarılı performans hayal etme & 0,805 & 0,522 \\
Kendi kendine konuşma & 1,741 & 0,140 \\
Düşünce ve fikirleri değerlendirme & 0,623 & 0,646 \\
Doğal ödüllere düşünceyi odaklama & 0,513 & 0,726 \\
\hline
\end{tabular}


Tablo 7 incelendiğinde kendini ödüllendirme, kendini gözlemleme, kendine hatırlatıcılar belirleme, kendine hedef belirleyerek başarılı performans hayal etme, kendi kendine konuşma, düşünce ve fikirleri değerlendirme ile doğal ödüllere düşünceyi odaklama boyutlarının $\mathrm{p}$ değerleri $0.05^{\prime}$ de büyüktür. Buna göre araştırmaya katılan personelin toplam çalışma süresi ile ifade edilen özliderlik boyutları arasında istatistiki olarak anlamlı bir farklılık yoktur.

Ancak kendini cezalandırma boyutu p değerleri 0,05' ten küçüktür. Buna göre araştırmaya katılan personelin toplam çalışma süresi ile ifade edilen özliderlik boyutu arasında istatistiki olarak anlamlı bir fark vardır. Toplam çalışma sürelerindeki hangi ikililer arasında anlamlı farklılık olduğunu anlamak için varyansları homojen olduğundan Tukey testi uygulanmıştır. Tukey testi sonuçları Tablo 8 de görüldüğü gibidir:

Tablo 8. Personelin toplam çalışma süresi ile öz liderlik boyutları arasındaki ilişkiye ilişkin ANOVA testindeki p değeri 0,05'ten küçük olan stratejilerin Tukey testi sonuçlarn

\begin{tabular}{|c|c|c|c|}
\hline Öz liderlik Boyutları & $\begin{array}{l}\text { Toplam Çalışma } \\
\text { Süresi }\end{array}$ & $\begin{array}{l}\text { Toplam Çalışma } \\
\text { Süresi }\end{array}$ & p \\
\hline \multirow{5}{*}{ Kendini cezalandırma } & $<5$ & $\begin{array}{l}6-10 \text { aras1 } \\
11-15 \text { aras1 } \\
16-20 \text { aras1 } \\
>20\end{array}$ & $\begin{array}{c}0,44 \\
0,34 \\
0,830 \\
0,173\end{array}$ \\
\hline & $6-10$ aras 1 & $\begin{array}{l}<5 \\
11-15 \text { aras1 } \\
16-20 \text { aras1 } \\
>20\end{array}$ & $\begin{array}{c}0,44 \\
0,958 \\
0,878 \\
1,0 \\
\end{array}$ \\
\hline & $11-15$ arası & $\begin{array}{l}<5 \\
6-10 \text { arası } \\
16-20 \text { arası } \\
>20 \\
\end{array}$ & $\begin{array}{c}0,34 \\
0,958 \\
0,670 \\
0,980 \\
\end{array}$ \\
\hline & $16-20$ arası & $\begin{array}{l}<5 \\
6-10 \text { aras1 } \\
11-15 \text { aras1 } \\
>20\end{array}$ & $\begin{array}{l}0,830 \\
0,878 \\
0,670 \\
0,923\end{array}$ \\
\hline & $>20$ & $\begin{array}{l}<5 \\
6-10 \text { aras1 } \\
11-15 \text { aras1 } \\
16-20 \text { aras1 }\end{array}$ & $\begin{array}{c}0,173 \\
1,0 \\
0,980 \\
0,923\end{array}$ \\
\hline
\end{tabular}


Tablo 8 incelendiğinde kendini cezalandırma boyutu için $<5$ ile $6-10$ arası ve $<5$ ile $11-15$ arası ikililerinin $p$ değeri $0,05^{\prime}$ ten küçüktür. Buna göre araştırmaya katılan personelin kendini cezalandırma boyutunu tercih etmede kurumdaki çalışma süresi $<5$ ile $6-10$ ve $<5$ ile $11-15$ yıl arasında istatistiki olarak anlamlı bir farklılık vardır.

Tablo 9. Yaş ile öz liderlik boyutları arasındaki ilişkiye ilişkin varyansların homojenliği testi sonuçları

\begin{tabular}{lcccc}
\hline \multicolumn{1}{c}{ Öz liderlik Boyutları } & Levene İstatistiği & df1 & df2 & p \\
\hline Kendini ödüllendirme & 1,800 & 4 & 400 & 0,128 \\
Kendini cezalandırma &, 679 & 4 & 400 & 0,607 \\
Kendini gözlemleme &, 267 & 4 & 400 & 0,899 \\
Kendine hatırlatıcılar belirleme &, 774 & 4 & 400 & 0,543 \\
Kendine hedef belirleyerek başarılı perfor- & 2,397 & 4 & 400 & 0,050 \\
mans hayal etme & & & & \\
Kendi kendine konuşma &, 397 & 4 & 400 & 0,811 \\
Düşünce ve fikirleri değerlendirme &, 854 & 4 & 400 & 0,492 \\
Doğal ödüllere düşünceyi odaklama & 1,935 & 4 & 400 & 0,104 \\
\hline
\end{tabular}

Tablo 9 incelendiğinde $\mathrm{p}$ değerlerinin $0,05^{\prime}$ ten büyük olduğu görülmektedir. $\mathrm{Bu}$ durumda varyanslar homojen (eşit) dağılmıştır. Varyanslar homojen dağıldığından dolayı tek yönlü anova testi sonuçlarına bakılabilir. Tek yönlü anova testi sonuçları aşağıdaki çizelgedeki gibidir:

Tablo 10. Yaş ile özliderlik boyutları arasındaki ilişkiye ilişkin ANOVA testi sonuçları

\begin{tabular}{lcc}
\hline \multicolumn{1}{c}{ Öz liderlik Boyutları } & $\mathbf{F}$ & $\mathbf{p}$ \\
\hline Kendini ödüllendirme & 2,860 & 0,023 \\
Kendini cezalandırma & 0,934 & 0,444 \\
Kendini gözlemleme & 2,914 & 0,021 \\
Kendine hatırlatıcılar belirleme & 1,532 & 0,192 \\
Kendine hedef belirleyerek başarılı performans hayal etme & 1,571 & 0,181 \\
Kendi kendine konuşma & 2,077 & 0,083 \\
Düşünce ve fikirleri değerlendirme & 1,693 & 0,151 \\
Doğal ödüllere düşünceyi odaklama & 1,800 & 0,128 \\
\hline
\end{tabular}

Tablo 10 incelendiğinde kendini cezalandırma, kendine hatırlatıcılar belirleme, kendine hedef belirleyerek başarılı performans hayal etme, kendi kendine konuşma, düşünce ve fikirleri değerlendirme ile doğal ödüllere düşünceyi odaklama boyutlarının $\mathrm{p}$ değerleri $0.05^{\prime}$ de büyüktür. 
Buna göre araştırmaya katılan personelin yaşı ile ifade edilen özliderlik boyutları arasında istatistiki olarak anlamlı bir farklılık yoktur.

Ancak kendini ödüllendirme ve kendini gözlemleme boyutlarının $p$ değerleri $0,05^{\prime}$ ten küçüktür. Buna göre araştırmaya katılan personelin yaşı ile ifade edilen özliderlik boyutları arasında istatistiki olarak anlamlı bir fark vardır. Yaş gruplarından hangi ikililer arasında anlamlı farklılık olduğunu anlamak için varyansları homojen olduğundan Tukey testi uygulanmıştır. Tukey testi sonuçları Tablo 11 de görüldüğü gibidir:

Tablo 11. Personelin yaşı ile öz liderlik boyutlan arasındaki ilişkiye ilişkin ANOVA testindeki p değeri 0,05'ten küçük olan stratejilerin Tukey testi sonuçları

\begin{tabular}{|c|c|c|c|}
\hline Öz liderlik Boyutları & Yaş & Yaş & $\mathrm{p}$ \\
\hline \multirow{20}{*}{ Kendini ödüllendirme } & \multirow{4}{*}{$<25$} & $26-34$ arası & 0,718 \\
\hline & & $35-44$ aras 1 & 0,063 \\
\hline & & $45-54$ arası & 0,073 \\
\hline & & $>55$ & 0,391 \\
\hline & \multirow{4}{*}{$26-34$ aras 1} & $<25$ & 0,718 \\
\hline & & $35-44$ aras 1 & 0,541 \\
\hline & & $45-54$ aras 1 & 0,479 \\
\hline & & $>55$ & 0,676 \\
\hline & \multirow{4}{*}{$35-44$ aras 1} & $<25$ & 0,063 \\
\hline & & $26-34$ aras 1 & 0,541 \\
\hline & & $45-54$ arası & 0,997 \\
\hline & & $>55$ & 0,938 \\
\hline & \multirow{4}{*}{$45-54$ arası } & $<25$ & 0,073 \\
\hline & & $26-34$ aras 1 & 0,479 \\
\hline & & $35-44$ aras 1 & 0,997 \\
\hline & & $>55$ & 0,973 \\
\hline & \multirow{4}{*}{$>55$} & $<25$ & 0,391 \\
\hline & & $26-34$ arası & 0,676 \\
\hline & & $35-44$ arası & 0,938 \\
\hline & & $45-54$ arası & 0,973 \\
\hline \multirow{11}{*}{ Kendini gözlemleme } & \multirow{4}{*}{$<25$} & $26-34$ arası & 0,057 \\
\hline & & $35-44$ aras 1 & 0,862 \\
\hline & & $45-54$ aras 1 & 0,166 \\
\hline & & $>55$ & 0,243 \\
\hline & \multirow{4}{*}{$26-34$ aras 1} & $<25$ & 0,057 \\
\hline & & $35-44$ arası & 0,410 \\
\hline & & $45-54$ aras 1 & 1,000 \\
\hline & & $>55$ & 0,819 \\
\hline & \multirow{3}{*}{$35-44$ arası } & $<25$ & 0,862 \\
\hline & & $26-34$ arası & 0,410 \\
\hline & & $45-54$ aras 1 & 0,604 \\
\hline
\end{tabular}




\begin{tabular}{lll}
\hline & $>55$ & 0,442 \\
\cline { 2 - 3 } $45-54$ aras 1 & $<25$ & 0,166 \\
& $26-34$ aras 1 & 1,000 \\
& $35-44$ aras 1 & 0,604 \\
& $45-54$ aras 1 & 0,837 \\
\hline \multirow{3}{*}{$>55$} & $26-34$ aras1 & 0,243 \\
& $35-44$ aras & 0,819 \\
& $45-54$ aras & 0,442 \\
& $>55$ & 0,837 \\
\hline
\end{tabular}

Tablo 11 incelendiğinde kendini ödüllendirme ve kendini gözlemleme boyutlarının ikilileri $\mathrm{p}$ değeri 0,05 'ten küçük değildir. Buna göre araştırmaya katılan personelin kendini ödüllendirme ve kendini gözlemleme boyutlarını tercih etmede yaş grupları arasında istatistiki olarak anlamlı bir farklılık yoktur.

Tablo 12. Öğrenim durumu ile özliderlik boyutları arasındaki ilişkiye ilişkin varyansların homojenliği testi sonuçları

\begin{tabular}{lcccc}
\hline \multicolumn{1}{c}{ Öz liderlik Boyutları } & Levene İstatistiği & df1 & df2 & p \\
\hline Kendini ödüllendirme &, 212 & 2 & 402 & 0,809 \\
Kendini cezalandırma & 1,195 & 2 & 402 & 0,304 \\
Kendini gözlemleme & 4,429 & 2 & 402 & 0,103 \\
Kendine hatırlatıcılar belirleme & 4,173 & 2 & 402 & 0,061 \\
Kendine hedef belirleyerek başarıllı perfor- &, 249 & 2 & 402 & 0,779 \\
mans hayal etme & & 2 & 402 & 0,513 \\
Kendi kendine konuşma &, 669 & 2 & 402 & 0,325 \\
Düşünce ve fikirleri değerlendirme & 1,126 & 2 & 402 & 0,051 \\
Doğal ödüllere düşünceyi odaklama & 3,512 & & & \\
\hline
\end{tabular}

Tablo 12 incelendiğinde $\mathrm{p}$ değerlerinin $0,05^{\prime}$ ten büyük olduğu görülmektedir. Bu durumda varyanslar homojen (eşit) dağılmıştır. Varyanslar homojen dağıldığından dolayı tek yönlü anova testi sonuçlarına bakılabilir. Tek yönlü anova testi sonuçları aşağıdaki çizelgedeki gibidir:

Tablo 13 incelendiğinde kendini ödüllendirme, kendini cezalandırma, kendine hatırlatıcılar belirleme, kendine hedef belirleyerek başarılı performans hayal etme, kendi kendine konuşma, düşünce ve fikirleri değerlendirme ile doğal ödüllere düşünceyi odaklama boyutlarının $p$ değerleri $0.05^{\prime}$ de büyüktür. Buna göre araştırmaya katılan personelin öğrenim 
durumu ile ifade edilen özliderlik boyutları arasında istatistiki olarak anlamlı bir farklılık yoktur.

Tablo 13. Öğrenim Durumu ile özliderlik boyutları arasındaki ilişkiye ilişkin ANOVA testi sonuçları

\begin{tabular}{lcc}
\hline Öz liderlik Boyutları & $\mathbf{F}$ & $\mathbf{p}$ \\
\hline Kendini ödüllendirme & 2,964 & 0,053 \\
Kendini cezalandırma & 0,684 & 0,505 \\
Kendini gözlemleme & 3,898 & 0,021 \\
Kendine hatırlatıcılar belirleme & 2,794 & 0,062 \\
Kendine hedef belirleyerek başarılı performans hayal etme & 2.218 & 0,110 \\
Kendi kendine konuşma & 2,913 & 0,055 \\
Düşünce ve fikirleri değerlendirme & 2,500 & 0,083 \\
Doğal ödüllere düşünceyi odaklama & 0,869 & 0,420 \\
\hline
\end{tabular}

Ancak kendini gözlemleme boyutunun $p$ değeri $0,05^{\prime}$ ten küçüktür. Buna göre araştırmaya katılan personelin öğrenim durumu ile kendini gözlemleme özliderlik boyutu arasında istatistiki olarak anlamlı bir fark vardır. Öğrenim durumlarından hangi ikililer arasında anlamlı farklılık olduğunu anlamak için varyansları homojen olduğundan Tukey testi uygulanmıştır. Tukey testi sonuçları Tablo 14 de görüldüğü gibidir:

Tablo 14. Personelin öğrenim durumu ile öz liderlik boyutları arasındaki ilişkiye ilişkin ANOVA testindeki p değeri 0,05'ten küçük olan stratejilerin Tukey testi sonuçları

\begin{tabular}{lccc}
\hline $\begin{array}{l}\text { Özliderlik } \\
\text { Stratejisi }\end{array}$ & \multirow{2}{*}{ Örenim Durumu } & Öğrenim Durumu & $\mathbf{p}$ \\
\hline \multirow{3}{*}{ Kendini } & \multirow{2}{*}{ Önlisans } & Lisans & 0,323 \\
gözlemleme & \multirow{2}{*}{ Lisans } & Lisansüstü & 0,360 \\
\cline { 2 - 4 } & \multirow{2}{*}{ Lisansüstü } & Önlisans & 0,323 \\
& & Lisansüstü & 0,024 \\
\cline { 2 - 4 } & & Önlisans & 0,360 \\
& & Lisans & 0,024 \\
\hline
\end{tabular}

Tablo 14 incelendiğinde kendini gözlemleme boyutu için lisans ve lisansüstü ikilisinin $\mathrm{p}$ değeri $0,05^{\prime}$ ten küçüktür. Buna göre araştırmaya katılan personelin kendini gözlemleme boyutunu tercih etmede öğrenim durumu lisans ve lisansüstü arasında istatistiki olarak anlamlı bir farklılık vardir. 


\section{Tartışma ve Sonuç}

Ankara ilinde hizmet sektöründe faaliyet gösteren kamu kurumlarında çalışan personelin özliderlik düzeylerini ölçmeye yönelik olarak gerçekleştirilen bu çalışmada toplam 486 kişiye ulaşılmış, elde edilen anketlerden ise 405 tanesi değerlendirmeye alınmıştır.

Araştırmaya katılan kamu personelinin en fazla "Kendini Gözlemleme" ve en az ise "Kendini Cezalandırma" özliderlik alt boyutununu tercih ettiği görülmektedir. Ayrıca diğer özliderlik alt boyutularının tercih düzeyleri de yüksektir.

Personelin cinsiyet ile öz liderlik boyutları arasındaki farklılaşma bağımsız örneklem $t$ testi ile analiz edilmiştir. Bu testin sonucunda sadece cinsiyet ile kendi kendine konuşma boyutu arasında istatistiki olarak anlamlı bir farklılık bulunmaktadır. Kadın çalışanların $(X=3,6216)$ kendi kedine konuşma stratejisini kullanma düzeyi erkek çalışanlardan $(X=$ $3,4015)$ daha yüksektir. Böylece $\mathrm{H}_{1}$ hipotezi (Personelin cinsiyeti ile öz liderlik boyutları arasında anlamlı bir ilişki vardır.) kendi kendine konuşma boyutu için kabul edilmiştir. Elde dilen sonuç, Arlı (2011) , Özsoy (2012), Demiröz(2015), Mert (2015), Arlı ve Avcı (2017) ve Akkuş (2018) tarafından yapılan çalışmalardan elde edilen sonuçlar ile benzerlik göstermektedir. Ancak Çakır (2015), Ağırman (2016) ve Senger (2014) tarafından yapılan araştırmalarda cinsiyet faktörünün öz liderlik boyutları üzerinde anlamlı bir farklılık bulunmadığı sonucuna varmışlardır.

Personelin toplam çalışma süresi ile öz liderlik boyutları arasındaki farklılaşma tek yönlü anova testi ile analiz edilmiştir. Bu testin sonucunda sadece kendini cezalandırma boyutu arasında istatistiki olarak anlamlı bir farklılık bulunmaktadır. Yapılan tukey testi sonucunda ise 5 yıl altı çalışma süresi ile 6 yıl - 10 yıl ve 11 yıl - 15 yıl arası çalışma süreleri arasında anlamlı bir farklılık bulunmaktadır. Kendini cezalandırma boyutunun toplam çalışma sürelerine göre ortalamalarına bakıldığında, toplam çalışma süresi arttıkça kendini cezalandırma boyutu tercih düzeyinin azaldığ1 görülmektedir. Böylece $\mathrm{H}_{2}$ hipotezi (Personelin toplam çalışma süresi ile öz liderlik boyutları arasında anlamlı bir ilişki vardır.) kendine cezalandırma boyutu için kabul edilmiştir. Özsoy'un (2012) çalışmasında toplam çalışma süresi ile yapıcı düşünce stratejileri arasında anlamlı bir ilişki bulunmuştur. Arlı'nın (2011) çalışmasında toplam 
çalışma süresi ile kendini ödüllendirme, kendi kendine konuşma ve düşünce ve fikirleri değerlendirme boyutları arasında anlamlı bir ilişki bulunmuştur. Ancak bu çalışmada elde edilen toplam çalışma süresi ile kendini cezalandırma boyutu arasındaki anlamlı ilişki ilgili çalışmalarda elde edilen sonuçlar ile uyuşmamaktadır.

Personelin yaşı ile öz liderlik boyutları arasındaki farklılaşma tek yönlü anova testi ile analiz edilmiştir. Bu testin sonucunda kendini ödüllendirme ve kendini gözlemleme boyutları arasında istatistiki olarak anlamlı bir farklılık bulunmaktadır. Yapılan tukey testi sonucunda ise kendini ödüllendirme ve kendini gözlemleme boyutları için yaş gruplarının kendi arasında karşılaştırmalarında anlamlı bir farklılık bulunmaktadır. Kendini ödüllendirme boyutunun personel yaşına göre ortalamalarına bakıldığında, yaş ilerledikçe kendini ödüllendirme boyutu tercih düzeyinin azaldığı görülmektedir. Kendini gözlemleme boyutunun personel yaşına göre ortalamalarına bakıldığında ise yaş ilerledikçe kendini gözlemleme boyutu tercih düzeyinin arttığ 1 görülmektedir. Böylece $\mathrm{H}_{3}$ hipotezi (Personelin yaşı ile öz liderlik boyutları arasında anlamlı bir ilişki vardır.) kendini ödüllendirme ve kendini gözlemleme boyutları için kabul edilmiştir. Demiröz (2015) tarafından yapılan çalışmada yaş ile tüm öz liderlik boyutları arasında anlamlı bir ilişki bulunmuştur. Arlı ve Avcı'nın (2017) çalışmasında ise yaş ile kendini ödüllendirme ve kendi kendine konuşma boyutları arasında anlamı bir ilişki bulunmaktadır. Bu sonuçlar çalışmamızdaki sonucu desteklemektedir. Ancak Arlı (2011), Özsoy (2012), Mert (2015) tarafından yapılan araştırmalarda yaş faktörünün öz liderlik boyutları üzerinde anlamlı bir farklılık bulunmadığı sonucuna varmışlardır.

Personelin öğrenim durumu ile öz liderlik boyutları arasındaki farklılaşma tek yönlü anova testi ile analiz edilmiştir. Bu testin sonucunda sadece öğrenim durumu ile kendini gözlemleme boyutu arasında istatistiki olarak anlamlı bir farklılık bulunmaktadır. Yapılan tukey testi sonucunda ise lisans ve lisansüstü eğitim durumu arasında anlamlı bir farklılık bulunmaktadır. Kendini gözlemleme boyutunun personel eğitim durumuna göre ortalamalarına bakıldığında, eğitim durumu arttıkça kendini gözlemleme boyutu tercih düzeyinin arttı̆g görülmektedir. Böylece $\mathrm{H}_{4}$ hipotezi (Personelin eğitim düzeyi ile öz liderlik boyutları arasında anlamlı bir ilişki vardır.) kendini gözlemleme boyutu için kabul edilmiştir. 
Elde dilen sonuç, Özsoy (2012) ve Demiröz (2015) tarafından yapılan çalışmalardan elde edilen sonuçlar ile benzerlik göstermektedir. Ancak Arlı'nın (2011) araştırmasında elde edilen sonuç araştırmamızdaki sonuç ile uyuşmamaktadır.

Öz liderlik boyutlarından kendine hatırlatıcılar belirleme, doğal ödüllere düşünceyi odaklama, kendine hedef belirleyerek başarılı performans hayal etme, düşünce ve fikirleri değerlendirme ile demografik özellikler arasında istatistiki olarak anlamlı farklılık bulunmamaktadır.

Benzer çalışmayı yapacak araştırmacıların yaşa ve çalışma süresine göre daha dengeli dağılmış bir örneklem üzerinde ve daha fazla kamu kurumuna ulaşarak çalışma yapması önerilir. Ayrıca kamu kurumlarındaki uzman, müfettiş, mühendis, doktor, teknisyen gibi daha fazla sayıda farklı kadrolarda çalışan personelin öz liderlik düzeyleri de farklılık gösterebilir. 
EXTENDED ABSTRACT

\title{
Determination of Self-Leadership Level in Public Organizations
}

\author{
Ercan Yavuz - Batuhan Ayan \\ Ankara Hacı Bayram Veli University
}

The concept of self-leadership has attracted the attention of many researchers from the time it was defined until today and the effects on the subjects such as performance, motivation and health have been investigated. In addition, various studies have been carried out on whether there is a relationship between self-leadership and personality, culture, occupational group. Sydänmaan-lakka (2004) uses the following statement to indicate the importance of the issue: "Self-leadership is fundamental to all leadership and management because if you cannot manage yourself, how can you lead others?". From the results of the researches in the literature, it is seen that the concept of self-leadership is an important and effective factor in reaching the levels that people want to reach in their lives and the goals they want to achieve.

Business conditions are different from the past. Public sectors are becoming more dynamic, complex and uncertain (Sejeli and Mansor, 2015 p.22). For this reason, public sector staff's self-management activities will affect the success of achieving organizational goals more positively. In this study, self-leadership levels of the personnel working in Ankara and working in the public sector in the service sector have been tried to be measured.

The concept of self-leadership was first developed and proposed by Manz $(1983,1986)$ and Manz and Neck (2004) as an extension of the theory of self-management (Topper, 2009 p.561). Manz (1983) defines the concept of self-leadership as a process in which individuals influence, direct and control their own behaviors by using specific cognitive and behavioral strategies to succeed (Carmeli, Meitar and Weisberg, 2006 p.76; Arlı and Avc1, 2017 p.456 ). The concept of self-leadership advocates that human beings can develop themselves and become leaders of themselves (Yavuz, 
2018 p.193). In other words, it is based on the claim that people manage themselves, and although people's behavior is exposed to external interventions, one's own inner motives ultimately shape their behaviors (Shek et al., 2015 p.343). Self-leadership strategies are generally divided into three basic categories: behavior-oriented strategies, natural reward strategies and constructive thinking model strategies. (Anderson and Prussia, 1997; Manz and Neck, 2004; Manz and Sims, 2001; Prussia et al., 1998; Houghton et al., 2003).

Behavior-oriented strategies should be done especially in the organization, but the unwillingness of the individual can be explained by the reluctance of this reluctance to believe that the task does not belong to him or that he believes in the contradiction of value judgments. (Neck and Houghton, 2006 p.271). Behavior-oriented strategies are self-punishment, self-observation, self-reminding, and natural reward strategies.

Natural reward strategies help people create pleasant and enjoyable features in their activities, so the tasks themselves are naturally rewarded. Natural reward strategies increase intrinsic motivation self-determination and feelings of competence. (Norris, 2008, p.45). There are two basic natural reward strategies. First, it involves giving more enjoyable and enjoyable features to a particular activity, so the task itself is naturally rewarded. The second strategy consists in distracting attention from the unpleasant aspects of a task and reorienting it with the rewards of rewards (Manz and Neck, 2004; Manz and Sims, 2001).

Constructive thinking strategies are the strategies that enable people to change the underlying thought patterns in the desired way (Müller and Niessen, 2017, p.3). Constructive thinking strategies create positive habit patterns and self-destructive speech is replaced by self-optimistic speech (Norris, 2008, p.45). Constructive thinking strategies are goal setting, imaginative performance imagining, self-talk and evaluation of thoughts and chants.

The aim of this study is to determine the self-leadership levels of personnel working in a public institution in Ankara. The hypotheses of the study are as follows:

- $\mathrm{H}_{1}$ : There is a significant relationship between the gender of staff and the dimensions of self-leadership. 
- $\mathrm{H}_{2}$ : There is a significant relationship between total working time of staff and self-leadership dimensions.

- $\mathrm{H}_{3}$ : There is a significant relationship between age of personnel and self-leadership dimensions.

- $\mathrm{H}_{4}$ : There is a significant relationship between the education level of personnel and the dimensions of self-leadership.

The universe of the study consists of staff in public institutions in Ankara, operating in the service sector. As the access to all public personnel in Ankara was very difficult, the entire research universe could not be reached. In the study, 486 personnel were reached, but 405 of the surveys were included in the study.

The research was conducted by Houghton and Neck (2002) in order to determine the levels of self-leadership behaviors of individuals and Tabak et al. (2009), which was adapted to Turkish by the Self Leadership Scale was used. In this scale, there are 3 strategies and 29 statements consisting of 8 dimensions.

The validity and reliability analyzes of the questionnaire used in this study were performed and the reliability coefficient of the scale was found to be 0.84 . The fact that this value is $\alpha>0.8$ indicates that the questionnaire has high reliability.

In the analysis, a significant relationship was found between the gender of the staff and the self-talk dimention, between working time of staff and self-punishment dimention, between age of staff and self-rewarding and self-observing dimensions and between education status of the staff and self-observation dimentions. In addition, a significant relationship was found between the demographic characteristics of the personnel and behavior oriented strategies.

\section{Kaynakça / References}

Akkuş, M. (2018). İlkokul ve ortaokul öğretmenlerinin öz-liderlikleri ile sinıf yönetimi öz yeterlik algıları arasındaki ilişki. (Yüksek Lisans Tezi), Gaziantep Üniversitesi, Gaziantep. 
Arlı, Ö. (2011). Bazı öncül ve ardıllarıyla öz liderlik: Ilköğretim öğretmenleri üzerine bir araştırma. (Yüksek Lisans Tezi), Kara Harp Okul, Ankara.

Ay, G. (2017). Yönetici ve yönetici asistanlarının öz liderlik düzeylerinin belirlenmesine yönelik bir araştırma. Uluslararası Sosyal Araştırmalar Dergisi, 10(52), 929-940.

Carmeli, A., Meitar, R. ve Weisberg, J. (2006). Self-leadership skills and innovative behavior at work. International Journal of Manpower, 27(1), 75-90.

D'Intino, R. S., Goldsby, M. G., Houghton, J. D. ve Neck, C. P. (2007). SelfLeadership: A Process for Entrepreneurial Success. Journal of Leadership and Organizational Studies, 13(4), 105-120.

Deci, E. ve Ryan, R. (1985). The support of autonomy and control of behavior. Journal of Personality and Social Psychology, 53, 1024-1037.

Demiröz, K. C. (2015). Genç çalışanların öz liderlik algılarıyla yöneticilerinin çatışma yönetimi tarzı arasındaki ilişkinin incelenmesi. (Doktora Tezi), Okan Üniversitesi, İstanbul.

Dilidüzgün, Ş. ve Emir, S. (2016). Özliderlik becerilerinin Türkçe öğretmen adaylarının metin dilbilim dersindeki başarılarına etkisi. Uluslararası Sosyal Araştırmalar Dergisi, 9(45), 545-554.

DiLiello, T. C. ve Houghton, J. D. (2006). Maximizing organizational leadership capacity for the future: Toward a model of self-leadership, innovation and creativity. Journal of Managerial Psychology, 21(4), 319-337.

Georgianna, S. (2007). Self-leadership: A cross-cultural perspective. Journal of Managerial Psychology, 22(6), 569 - 589.

Georgianna, S. (2015). Assessing and developing entrepreneurs' self-leadership and super-leadership. Journal of Entrepreneurship and Organization Management, 4(3), DOI: 10.4172/2169-026X.1000146

Godwin, J. L., Neck, C. P. ve Houghton, J. D. (1999). The impact of thought self-leadership on individual goal performance: A cognitive perspective. Journal of Management Development, 18(2), 153 - 170.

Hauschildt, K. ve Konradt, U. (2012). Self-leadership and team members' work role performance. Journal of Managerial Psychology, 27(5), 497 - 517. 
Houghton, J. D. ve Neck, C. P. (2002). The revised self-leadership questionnaire. Journal of Managerial Psychology, 17(8), 672-691.

Houghton, J. D., Bonham, T., Neck, C. P. ve Singh, K. (2004). The relationship between self-leadership and personality A comparison of hierarchical factor structures. Journal of Managerial Psychology, 19(4), 427-441.

İraz, R., Çakıcı, A. B. ve Tekin, İ. Ç. (2014). Yenilik yönetimi açısından kobilerde dış kaynak kullanımının araştırılması: Konya İli Örneği. Global Journal of Economics and Business Studies, 3(6), 51-68.

Jensen, J., 2, C. N. ve Beaulieu, R. (2016). The self-action leadership model: a qualitative, nomological expansion of self-leadership theory rooted in action research theory. Dissertation, 2016070070 .

Malmir, A. ve Azizzadeh, F. (2013). Evaluating and Providing solutions for self-leadership. International Public Management Review, 14(2), 66-86.

Manz, C. C. ve Neck, C. P. (2004). Mastering self-leadership: Empowering yourself for personal excellence (Third edition). Upper Saddle River, NJ: Pearson Prentice Hall.

Manz, C. C. ve Sims, H. P. (2001). The new Superleadership: Leading others to lead. Berrett-Koehler: San Francisco, CA.

Mert, Gülnur (2015). Sağlık çalışanlarının öz liderlik algıları ve çatışma yönetim stilleri arasındaki ilişki. Akademik Sosyal Araştırmalar Dergisi, 3(20), 69-78

Müller, T. ve Cornelia Niessen. (2018). Self-leadership and self-control strength in the work context. Journal of Managerial Psychology, 33(1), 74-92.

Neck, C. P. ve Houghton, J. D. (2006). Two decades of self-leadership theory and research: Past developments, present trends, and future possibilities. Journal of Managerial Psychology, 21(4), 270 - 295.

Norris, S. E. (2008). An examination of self-leadership. Emerging Leadership Journeys, 1(2), 43-61.

Özgür Arlı, A. A. (2017). Öz kendilik değerlendirmesinin öz liderlik davranışları üzerinde etkisi: Ilköğretim öğretmenleri üzerine bir araştırma. Mehmet Akif Ersoy Üniversitesi Sosyal Bilimler Enstitüsü Dergisi, 9(22), 455-468. 
Özsoy, İ. (2012). Örgüt iklimi, öz liderlik ve iş tatmininin Ar-Ge performansına etkisi: Savunma sanayiinde bir araştırma. (Yüksek Lisans Tezi). Kara Harp Okulu, Ankara.

Phillips, J. I., Kern, D., Tewari, J., Jones, K. E., Beemraj, E. P. ve Ettigi, C. A. (2017). Self-leadership change project: the continuation of an ongoing experiential program. Education + Training, 59(3), 323-334.

Ricketts, K. G., Carter, H. S., Place, N. T. ve McCoy, T. (2012). A look inside: Self-leadership perceptions of extension educators. Journal of Extension, 50(5), . https://joe.org/joe/2012october/a3.php adresinden 26.02.2018 tarihinde erişildi.

Sejeli, D. S. ve Mansor, N. A. (2015). Leadership derailment: Does selfleadership matters? International Journal of Economics and Financial Issues, 5, 22 - 26.

Sesen, H., Tabak, A. ve Arli, O. (2017). Consequences of Self-leadership: A study on primary school teachers. Educational Sciences: Theory and Practice, 17(3), 945-968.

Shek, D. T., Ma, C. M., Liu, T. T. ve Siu, A. M. (2015). The role of selfleadership in service leadership. International Journal on Disability and Human Development, 14(4),343-350.

Sydänmaanlakka, P. (2004, 05 02). https://www.pertec.fi/pertec_front_page_fi: https://www.pertec.fi/userfile/files/files/Artikeli\%20What\%20is\%20Self-Leadership.pdf adresinden alınd1

Tabak, A., Sığrı, Ü. ve Türköz, T. (2013). Öz liderlik ölçeğinin Türkçeye uyarlanması çalışması. Bilig, 67, 213-246.

Topper, E. F. (2009). Self-leadership: Road to Personal Excellence. New Library World, 110(11/12), 561 - 563.

\section{Kaynakça Bilgisi / Citation Information}

Yavuz, E. ve Ayan, B. (2019). Kamu örgütlerinde öz liderlik düzeyinin belirlenmesi. OPUS-Uluslararası Toplum Araştırmaları Dergisi , 10(17), 1002-1029. DOI: 10.26466/opus.513433 